\title{
Influence of parameters of deep grinding on nano-hardness and surface roughness of C45 steel
}

\author{
Wpływ parametrów szlifowania wgłębnego \\ na nanotwardość i chropowatość powierzchni stali C45
}

\author{
MARIUSZ DEJA \\ ALICJA STANIS $Ł A W S K A$ \\ MAREK SZKODO \\ KAROLINA WSZELAK *
}

The paper presents the results of investigations on the effect of the depth of concurrent grinding of flat surfaces on the roughness and nano-hardness of the surface layer of C45 steel with a ferritic-pearlitic structure and average grain size of $20 \mu \mathrm{m}$. A significant increase in the hardness of the surface layer of the workpiece was obtained for all grinding depths.

KEYWORDS: grinding, nano-hardness, state of the surface layer, ferritic-pearlitic structure, deformation strengthening

The selection of technological parameters in the finishing process allows to meet the assumed design requirements. Properly carried out grinding process allows obtaining a high dimensional and shape accuracy, the appropriate state of the surface layer, as well as the required geometric structure of the surface [1,2]. Modeling and optimization of the grinding process are usually aimed at achieving a low surface roughness and high machining efficiency [3].

The choice of machining parameters is a factor determining the distribution of hardness and stresses in the surface layer of the workpiece made of material with a defined volume fraction of structure components, which in turn affects, among others, for wear resistance of the treated surface $[4,5]$.

\section{Experimental research}

- Sample preparation. Workpieces with a height of 10 $\mathrm{mm}$ were cut from a C45 steel bar with a diameter of $50 \mathrm{~mm}$ on an AccuteX AU-300IA wire cutter. They were subjected to a heat treatment involving normalizing annealing at $850^{\circ}$ $\mathrm{C}$ for $20 \mathrm{~min}$, followed by cooling in still air.

After heat treatment, a ferritic-pearlitic structure was obtained (fig. 1) with an average grain size of $20 \mu \mathrm{m}$. In the normalized state, the steel had the following mechanical properties: tensile strength - $490 \mathrm{MPa}$ and hardness - $167 \mathrm{HB}$ [6].

\footnotetext{
* Dr hab. inż. Mariusz Deja (mariusz.deja@pg.edu.pl), mgr inż. Alicja Stanisławska (alicja.stanislawska@pg.edu.pl), mgr inż. Karolina Wszelak (karolina.wszelak@pg.edu.pl) - Katedra Technologii Maszyn i Automatyzacji Produkcji, Wydział Mechaniczny Politechniki Gdańskiej; dr hab. inż. Marek Szkodo (marek.szkodo@pg.edu.pl) - Katedra Inżynierii Materiałowej i Spajania, Wydział Mechaniczny Politechniki Gdańskiej
}

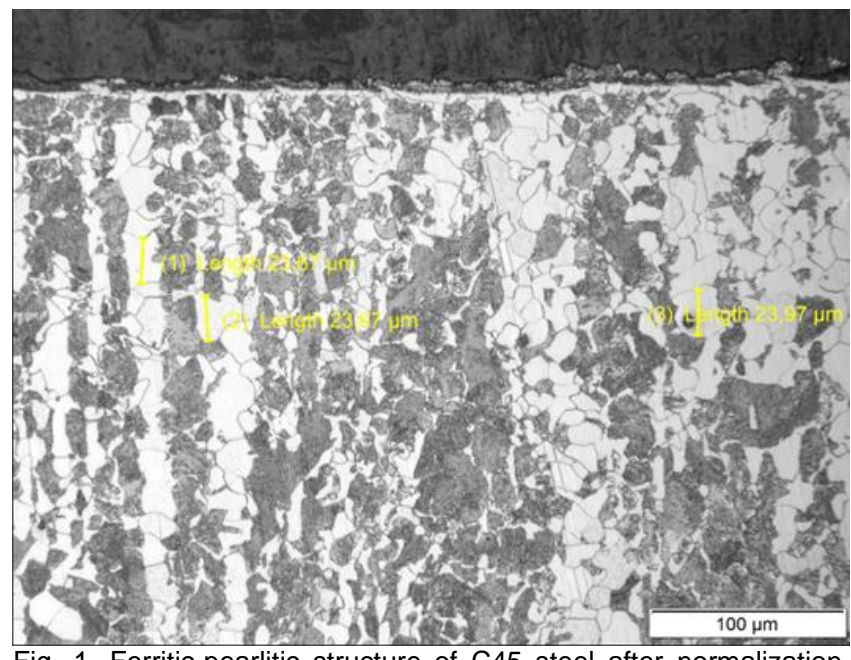

Fig. 1. Ferritic-pearlitic structure of C45 steel after normalization. Sample digested with Nital. Photograph taken with LM Leice light microscope

- Test conditions. The grinding was carried out on a CNC grinding machine SPG $25 \times 60$ with a horizontal spindle axis. The Norton grinding wheel with precious alumina grains with technical characteristics 38A60LVS and dimensions: diameter $250 \mathrm{~mm}$ and width $25 \mathrm{~mm}$ was used for machining. Each test was preceded by the conditioning of the grinding wheel using a single-grain diamond dresser with the following parameters set in the control program:

- depth $a_{\mathrm{ed}}$ at a single pass: $0.1 \mathrm{~mm}$,

- number of dressing passes: 4,

- circumferential speed of the grinding wheel: $v_{\mathrm{sd}}=23 \mathrm{~m} / \mathrm{s}$,

- lateral feed of the grinding wheel: $f_{\mathrm{ad}}=0.2 \mathrm{~mm} / \mathrm{rev}$.,

- number of shifting passes: 2.

Concurrent deep grinding is carried out with the use of coolant, at constant circumferential speed of the grinding wheel $v_{\mathrm{s}}=25 \mathrm{~m} / \mathrm{s}$ and constant feed speed $v_{\mathrm{ft}}=1 \mathrm{~m} / \mathrm{min}$. The variable parameter was the grinding depth set in subsequent tests according to the values: $a_{\mathrm{e}}=2 ; 8 ; 14 ; 20$ $\mu \mathrm{m}$ The minimum depth $a_{\mathrm{e}}=2 \mu \mathrm{m}$ was accepted due to the low hardness of the workpiece.

In each test, a new workpiece with a ferritic-pearlitic structure obtained after heat treatment was grinded (fig. 1). 
In order to ensure the same depth of grinding, the workpiece after fixing on the magnetic table was leveled by whitening with the depth $a_{\mathrm{e}}=1 \mu \mathrm{m}$.

- Measuring apparatus. Nano-hardness tests were carried out on a nanoindenter (NanoTest Vantage, Micro Materials, UK) using a pyramidal, diamond, three-ventral Berkovich indenter with an apical angle of $124.4^{\circ}$.

Each sample was subjected to nanoindentation measurements with maximum force values of 50, 100 and $500 \mathrm{mN}$, respectively.

Fig. 2 presents exemplary curves obtained in the nanoindentation test performed on the surface of the workpiece after grinding with a depth of $a_{e}=2 \mu \mathrm{m}$, with the maximum load of the indenter of $50 \mathrm{mN}$. The time of force increase from the zero value was $20 \mathrm{~s}$, the holding time with the maximum force value $-5 \mathrm{~s}$, and the unloading time -20 s. Individual indentations were $50 \mu \mathrm{m}$ apart. During the measurement, the load curve was recorded as a function of the Berkovich indentation. The value of nano-hardness $(H)$ was determined using the Oliver-Pharra method in the NanoTest program.

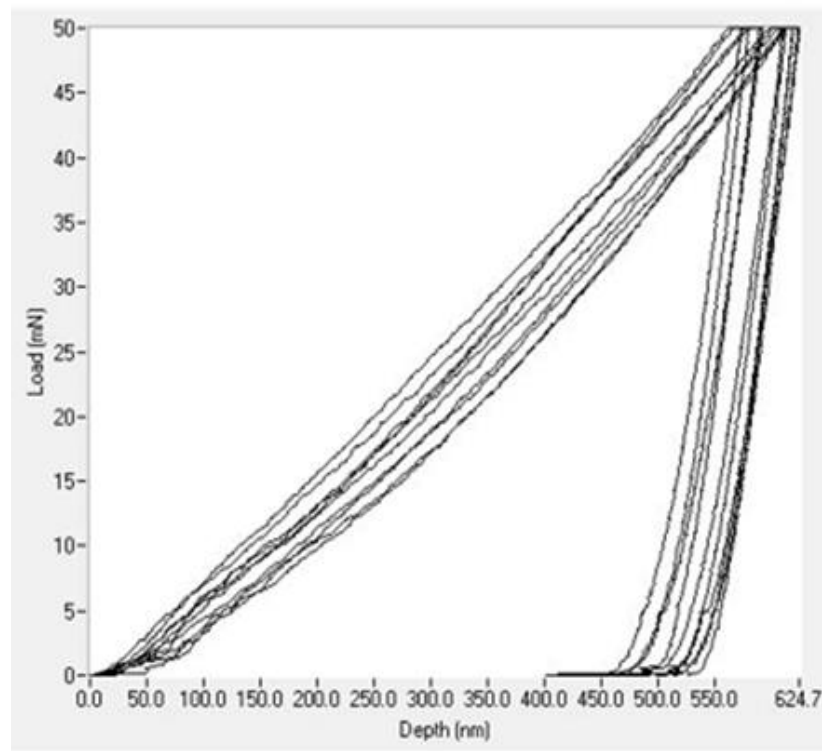

Fig. 2. Exemplary load curves as a function of depth of the Berkovich indentation depth; measurement on the workpiece surface made of C45 steel after grinding with depth $a_{\mathrm{e}}=2 \mu \mathrm{m}$

Surface topographies were examined with atomic force microscopy (AFM, NaniteAFM, Great Britain) using a contactless module with a force of $55 \mathrm{mN}$ in the $50 \times 50 \mu \mathrm{m}$ area. Surface roughness parameter Sa was determined.

\section{Research results and discussion}

The influence of the grinding depth on the nano-hardness of the surface layer of C45 steel with an average grain size of $20 \mu \mathrm{m}$, with different maximum indentation loads, is presented in the table and in fig. 3.

The hardness of the surface layer differed depending on the depth of grinding and the maximum load on the indenter. The smallest hardness variability range, $2.9 \div 3.4 \mathrm{GPa}$, was recorded for a maximum load of $500 \mathrm{mN}$. An almost double increase in hardness was obtained compared to the initial state after normalization, in which the hardness was 167 $\mathrm{HB}$, i.e. about $1.67 \mathrm{GPa}$. The standard deviation for the measurements was relatively small and was within $0.2 \div 0.3$ GPa.

As shown by metallographic examinations using a scanning microscope (fig. 4), plastic deformations in both the ferrite grains and perlite grains were formed at a depth of $2 \mu \mathrm{m}$, which contributed to an almost two-fold increase in hardness in the surface layer.
TABLE. Nano-hardness and surface roughness parameter Sa after concurrent deep grinding of $\mathrm{C} 45$ steel objects with an average grain size of $20 \mu \mathrm{m}$

\begin{tabular}{|c|c|c|c|}
\hline \multicolumn{4}{|c|}{ Grain $20 \mu \mathrm{m}$} \\
\hline $\begin{array}{l}\text { Grinding depth, } \\
\mathrm{mm}\end{array}$ & $\begin{array}{c}\text { Force, } \\
\mathrm{mN}\end{array}$ & $\begin{array}{c}\text { Nano- } \\
\text { hardness, } \\
\text { GPa }\end{array}$ & $\begin{array}{l}\text { Roughness } \\
\text { Sa, nm }\end{array}$ \\
\hline \multirow{3}{*}{0.002} & 50 & 5.59 & \multirow{3}{*}{82.542} \\
\hline & 100 & 4.79 & \\
\hline & 500 & 3.40 & \\
\hline \multirow{3}{*}{0.008} & 50 & 7.53 & \multirow{3}{*}{81.608} \\
\hline & 100 & 7.10 & \\
\hline & 500 & 3.47 & \\
\hline \multirow{3}{*}{0.014} & 50 & 5.59 & \multirow{3}{*}{91.455} \\
\hline & 100 & 4.19 & \\
\hline & 500 & 3.00 & \\
\hline \multirow{3}{*}{0.020} & 50 & 7.49 & \multirow{3}{*}{113.31} \\
\hline & 100 & 7.49 & \\
\hline & 500 & 2.90 & \\
\hline
\end{tabular}

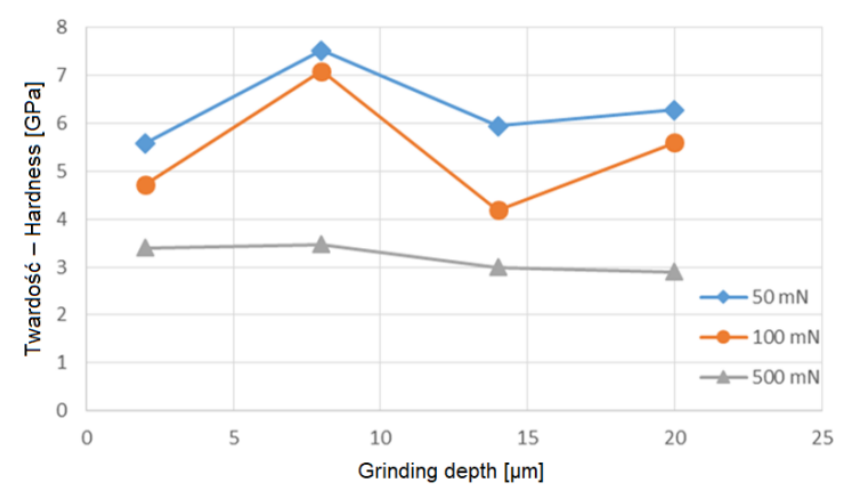

Fig. 3. Influence of the grinding depth on the hardness of the surface layer of $\mathrm{C} 45$ steel with an average grain size of $20 \mu \mathrm{m}$, with different maximum indentation loads

During the nanoindentation test, using a maximum load of $500 \mathrm{mN}$, the indenter delved into approx. $2600 \mathrm{~nm}$ $\pm 100 \mathrm{~nm}$, which is assumed to be the minimum depth for the deformation of the material for a given load. At a lower maximum load in the nanoindentation test, $50 \mathrm{mN}$ and $100 \mathrm{mN}$ respectively, a greater increase in the hardness of the surface layer was noted. The hardness variability range was $4.17 \div 7.1 \mathrm{GPa}$ for $100 \mathrm{mN}$ load and $5.59 \div 7.53 \mathrm{GPa}$ for $50 \mathrm{mN}$ load. At $50 \mathrm{mN}$ load, the indenter penetrated into the material at approx. $600 \mathrm{~nm} \pm 20 \mathrm{~nm}$, and at $100 \mathrm{mN}$ load - to a depth of $950 \mathrm{~nm} \pm 50 \mathrm{~nm}$. As expected, the hardness increased due to the deformation of ferrite grains and perlite grains after grinding, while the hardness in the surface layer of the ground workpiece surface decreased with the distance from this surface into the material.

As can be seen in fig. 3, the hardness distribution in the surface layer of the workpiece surface, resulting from the different indentation of the indentations used, also depended on the depth of grinding. The greatest surface hardness (for a load of $50 \mathrm{mN}$ ) - 7.53 GPa - was achieved for the grinding depth $a_{\mathrm{e}}=8 \mu \mathrm{m}$.

In the case of a larger grinding depth $-14 \mu \mathrm{m}$ and $20 \mu \mathrm{m}$, other hardness distributions were obtained from the workpiece surface into the material. As shown in fig. 3 , the maximum hardness at the workpiece surface for these grinding depths was about $6 \mathrm{GPa}$. This hardness is approx. $20 \%$ lower than after sanding with depth $a_{e}=8 \mu \mathrm{m}$. As in the case of grinding with smaller depths, also here there was a decrease in hardness along with the distance from the ground workpiece surface, with a larger drop for the grinding depth of $14 \mu \mathrm{m}$ than for $20 \mu \mathrm{m}$.

The metallographic examination of the workpiece surface layer polished with a depth of $a_{\mathrm{e}}=20 \mu \mathrm{m}$, made with the use of a scanning microscope, revealed an additional layer of 
changed material with a clear limit of separation from ferrite and pearlite grains. This layer adhered well to the ferriticpearlitic substrate - fig. 5 .

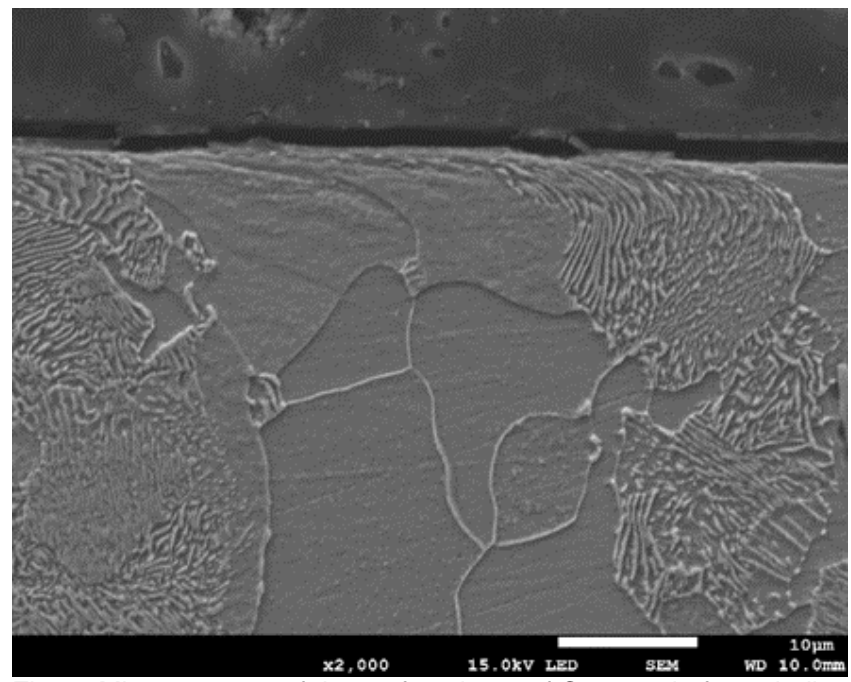

Fig. 4. Microstructure of the surface layer of C45 steel after grinding with a depth of $2 \mu \mathrm{m}$. Visible plastic deformation of perlite and ferrite grains (JEOL JSM-7800 F scanning electron microscope)

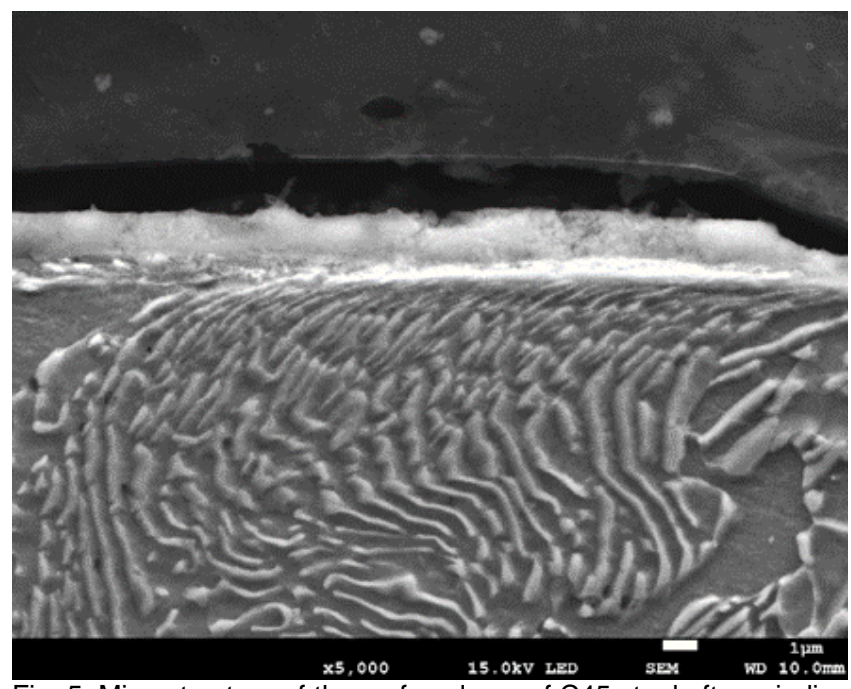

Fig. 5. Microstructure of the surface layer of C45 steel after grinding with a depth of $20 \mu \mathrm{m}$. Visible oxidized surface layer with a thickness of approx. 3-4 $\mu \mathrm{m}$, under which there is a plastically deformed pearlite grain (JEOL JSM-7800 F scanning electron microscope)

The influence of the grinding depth on the workpiece surface roughness is shown in fig. 6 . The surface roughness parameter Sa remained at the same level for the two initial grinding depths. Roughness increase occurred with the increase of the grinding depth - from $a_{\mathrm{e}}=14 \mu \mathrm{m}$.

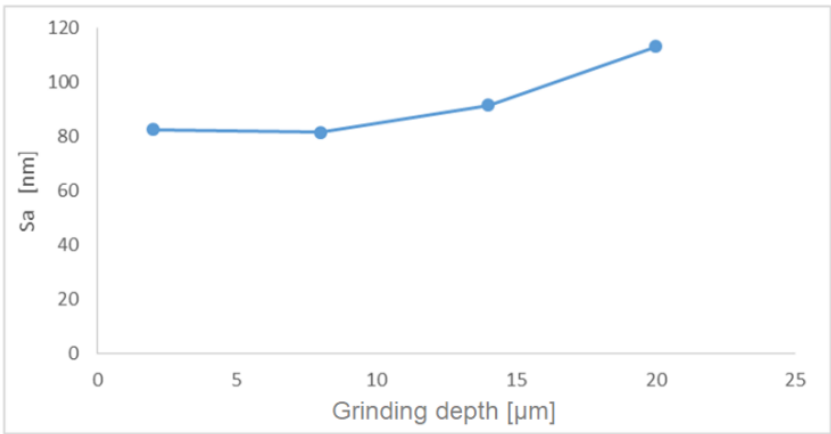

Fig. 6. Influence of the grinding depth on the surface roughness of C45 steel objects with an average grain size of $20 \mu \mathrm{m}$

\section{Conclusions}

Based on the results of the research, the following conclusions can be made:

- Grinding of normalized C45 steel with an average grain size of $20 \mu \mathrm{m}$ with the given parameters results in a significant increase in hardness of the surface layer of the processed material.

- The greatest increase in hardness of the surface layer occurred in the case of grinding with a depth of $a_{\mathrm{e}}=8 \mu \mathrm{m}$. The hardness of the material at the workpiece surface amounted to $7.53 \mathrm{GPa}$, which means a four and a half increase in hardness compared to the hardness of the material before grinding. This increase was caused by the deformation of both ferrite and pearlite grains.

- When sanding steel with a depth of $14 \mu \mathrm{m}$ and $20 \mu \mathrm{m}$, the increase in hardness was less than at the sanding depth of $8 \mu \mathrm{m}$. The hardness at the surface of the surface layer after grinding was $6 \mathrm{GPa}$, which means an increase of $350 \%$ in relation to the hardness of the material before grinding.

- The surface roughness parameter Sa was maintained at the same level for the two initial grinding depths of $2 \mu \mathrm{m}$ and $8 \mu \mathrm{m}$. Roughness increase occurred with the increase of the grinding depth from $a_{\mathrm{e}}=14 \mu \mathrm{m}$.

\section{REFERENCES}

1. Oczoś K.E., Porzycki J. „Szlifowanie: podstawy i technika”. Warszawa: Wydawnictwa Naukowo-Techniczne, 1986.

2. Uhlmann E. et al. „Influence of rail grinding process parameters on rail surface roughness and surface layer hardness". Wear. 366367 (2016): pp. 287-293.

3. Janardhan M. „An integrated evaluation approach for modelling and optimization of surface grinding process parameters". Materials Today: Proceedings. 2 ( 2015 ): pp. 1622-1633.

4. Denkena B., Grove T., Lucas H. „Influences of grinding with Toric CBN grinding tools on surface andsubsurface of 1.3344 PM steel". Journal of Materials Processing Technology. 229 (2016): pp. 541-548.

5. Sadat Zoei M., Hosein Sadeghi M., Salehi M. „Effect of grinding parameters on the wear resistance and residual stress of HVOFdeposited WC-10Co-4Cr coating". Surface \& Coatings Technology. 307 (2016): pp. 886 $\div 891$

6. Dobrzański L.A. „Metalowe materiały inżynierskie”. Wydawnictwo naukowo-techniczne, 2004.
Translation of scientific articles, their computer composition and publishing them on the website www.mechanik.media.pl by original articles in Polish is a task financed from the funds of the Ministry of Science and Higher Education designated for dissemination of science.

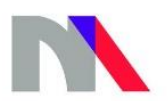

Ministry of Science and Higher Education

Republic of Poland 